\title{
CONVERGES OF SKYYOGA AND KAYAKALPA ON THE CORE MUSCLE STRENGTH AND AGEING FACTOR
}

\section{K. Krishnaveni}

Dr. M. Jothilakshmi*
M. Phil.Scholar Bharathiar University Coimbatore

Asst. Professor Department OfYoga For Human Excellence WCSCVision - Sky Vision Centre, Aliyar, Pollachi *Corresponding Author

INTRO: Today's generation children are growing faster in all aspects mentally, physiologically and physically too than before generation. The life span of the human being got reduced to averagely 63 age, value tells more than the words and What will be the future? Are the children are not going to see their grandfather and grandmother? These are the question which lead this study to overtaken.

METHOD: The college boys from in and around Coimbatore were selected as subjects for the propose of study. The total 60 subjects were selected and they age in 18 to 21 years. Then subjects were divided into three groups, each containing 20 members. Experimental Group I given SKY yoga with Kayakalpa training and Experimental Group II were given only SKY yoga training for 5 days in week for 10 weeks and control group not given any training.

RESULTS: The study shown that there was improvement in the coordination of hand- mind and ability to think measured by Shuttle cross pick-up test method to the Experimental groups I \& II than the subjects in control group. The coordination of hand- mind has increased this shown that SKY yoga effects the neurological system and mental ability of the body.

CONCLUSION: The result shown that SKYYoga with Kayakalpa on college students has positively impact on the core muscles and ageing factor.

\section{INTRODUCTION}

When the human gets older in the young age this leads to many problems in the future like immunity, weaker, heart problem, infertility etc., Wow there comes the question this generation people are not going to see their grandson. Practices of yoga develop the awareness of the interrelation between the emotional, mental and physical levels, and about how a disturbance in any one of these affects the others. Gradually, this awareness leads to an understanding of the generation gap to bonded. Kayakalpa yoga is most important in SKY yoga, since it increase our vital energy. In term "Kaya" is "body" and "Kalpa" is "immortal" so it is termed Kayakalpa yoga. It helps to not only cure and prevent disease, it helps the practitioner from many problems and troubles of aging. The science behind Kayakalpa yoga is derived from the horse.

\section{OBJECTIVE OF THE STUDY:}

The main vision of the study is to show fact of the improvement in core muscle strengthen due to tissue development by the fact of ageing got reduced in our body by the help of SKY yoga and Kayakalpa. Hence this study is undergone to find the impact of SKY yoga and Kayakalpa on the core muscles get improved by tissue development.

\section{STATEIMENT OFTHE PROBLEM:}

The unknown factor which influencing the health and weakening the body strength is ageing factor. When young generation get the older not only in body strength even in mentally and physiologically which get reduces the life span.

\section{HYPOTHESIS}

It is being hypnotised there would be improvement on core muscle strength measured by selected physical variable of Plank Fitness test by the practices of SKYYoga and Kayakalpa.

\section{LIMITATIONS}

1. The encouraging factors influencing the study were not considered.

2. Food, sleep, economy etc., were not taken into consideration.

3. The daily activity was not controlled.

4. The heredity problem was not considered.

\section{METHODOLOGY:}

For this study 60 college boy students from Coimbatore were selected. They undergone pre-test on physical variable of Plank fitness test. Then the subjects were divided into three groups with equal number subjects in random manner. Experimental Group I given SKY yoga with Kayakalpa training and other subject mates are allowed to encourage the subjects during the test, Experimental Group II were given only SKY yoga training for 5 days in week for 10 weeks and Control group were not given any kind of training till the period of experiment. The post-test has taken after the 10 weeks of training for the experimental students and control group.

\section{VARIABLES SELECTED FOR EXPERIMENT DEPENDENTVARIABLES: PHYSICALVARIABLES}

\section{- The Plank Fitness Test}

It also known as the Prone Bridge Test, is a simple fitness test of core muscle strength, and can also be used as a fitness exercise for improving core strength.

\section{PURPOSE:}

The plank test measures the control and endurance of the back/core stabilizing muscles.

\section{EQUIPIENT REQUIRED:}

Flat and clean surface, stopwatch, recording sheets, pen.

\section{PRE-TEST:}

Explain the test procedures to the subject before the test. Perform screening of health risks and obtain informed consent. Prepare note basic info such as age, height, body weight, gender and test conditions. Perform a standard warmup. See more details of pre-test procedures.

\section{PROCEDURE:}

The aim of this test is to hold an elevated position for as long as possible. Start with the upper body supported off the ground by the elbows and forearms, and the legs straight with the weight taken by the toes. The hip is lifted off the floor creating a straight line from head to toe. As soon as the subject is in the correct position, the stopwatch is started. The head should be facing towards the ground and not looking forwards. The test is over when the subject is unable to hold the back straight and the hip is lowered.

\begin{tabular}{|c|c|c|}
\hline Submitted : $07^{\text {th }}$ July,2019 & Accepted : 24 ${ }^{\text {th }}$ July,2019 & Publication : 15 ${ }^{\text {th }}$ November, 2019 \\
\hline www.worldwidejournals.com $\mid$ & & \\
\hline
\end{tabular}




\section{SCORING}

The score is the total time completed. The table below is just a rough guide to scores for both males and females which I made up.

\begin{tabular}{|l|l|}
\hline Rating & Time \\
\hline Excellent & $>6$ minutes \\
\hline Very Good & $4-6$ minutes \\
\hline above average & $2-4$ minutes \\
\hline Average & $1-2$ minutes \\
\hline below average & $30-60$ seconds \\
\hline
\end{tabular}

\begin{tabular}{|l|l|}
\hline poor & $15-30$ seconds \\
\hline very poor & $<15$ seconds \\
\hline
\end{tabular}

\section{ADVANTAGES:}

This test is simple to perform, with minimal costs and can be self-administered.

\section{DATA ANALYSIS:}

For statistical analysis the data gathered from the pre-test and the post test on breath holding rate of experimental groups and control group have been existed in Table I

Table I Analysis of Covariance for the pre-test and post test data on Plank Fitness Test

\begin{tabular}{|c|c|c|c|c|c|c|c|}
\hline TEST & GROUPI & GROUP2 & GROUP3 & $\mathrm{df}$ & SS & MOS & F value \\
\hline \multirow[t]{2}{*}{ Pre } & \multirow[t]{2}{*}{47.65} & \multirow[t]{2}{*}{45.7} & \multirow[t]{2}{*}{47.5} & 2 & 47.1 & 23.55 & \multirow[t]{2}{*}{$3.12 *$} \\
\hline & & & & 57 & 4193.75 & 73.57 & \\
\hline \multirow[t]{2}{*}{ Post } & \multirow[t]{2}{*}{128.85} & \multirow[t]{2}{*}{61.5} & \multirow[t]{2}{*}{48.4} & 2 & 74532.23 & 37266.12 & \multirow[t]{2}{*}{$603.39 *$} \\
\hline & & & & 57 & 3520.35 & 61.76 & \\
\hline \multirow[t]{2}{*}{ Adjusted } & \multirow[t]{2}{*}{128.69} & \multirow[t]{2}{*}{61.78} & \multirow[t]{2}{*}{48.27} & 2 & 74025.93 & 37012.96 & \multirow[t]{2}{*}{$627.2^{*}$} \\
\hline & & & & 56 & 3304.718 & 59.012 & \\
\hline
\end{tabular}

Table I shows that the adjusted post-test means values of Plank Fitness Test for SKY yoga with Kayakalpa Group, SKY yoga Group and Control Group are 128.69, 61.78 and 48.27 respectively.The attained F-ratio of 627.2 for adjusted posttest mean is very much higher than the table value of 3.16 for $\mathrm{df} 2$ and 56 required for significant at 0.05 level of confidence.

The outcomes of the study point out that there are substantial differences among the adjusted post-test means of SKY yoga with Kayakalpa Group, SKY yoga practice only Group and Control Group on the Plank Fitness Test.

To conclude which of the paired means had a substantial difference, the Scheffe's test was applied as Post hoc test and the results are presented in Table II.

Table II Scheffe's test for the variances between the adjusted post-test paired means on Plank Fitness Test

\begin{tabular}{|c|c|c|c|c|}
\hline \multicolumn{3}{|c|}{ Groups } & Mean & CD \\
\cline { 1 - 4 } Exp Groupl & Exp Group2 & Cnt Group & & \\
\hline 128.69 & 61.78 & & 66.907 & 19.909 \\
\hline 128.69 & & 48.27 & 80.416 & \\
\hline & 61.78 & 48.27 & 13.508 & \\
\hline
\end{tabular}

Table II shows that the adjusted post-test means differences on SKY yoga with Kayakalpa Group and SKY yoga practice only Group, SKY yoga with Kayakalpa Group and Control Group, SKY yoga practice only Group and Control Group are $66.907,80.416$ and 13.508 respectively. The value 19.909 which shows major differences at 0.05 level of confidence.

It could be determined from the results of the study that there is a significant difference in Plank Fitness Test between the adjusted post-test means of SKY yoga with Kayakalpa Group, SKY yoga practice only Group and Control Group. However, the improvements in the Plank Fitness Test were significantly higher for SKY yoga with Kayakalpa Group than SKY yoga only practice Group and Control Group. It could be also seen that SKY yoga with Kayakalpa Group and SKY yoga only practice had strengthened the core muscle than Control Group.

The mean and adjusted values of pre and posttest of SKY yoga with Kayakalpa Group and SKY yoga only practice Group and Control Group on Plank Fitness Test are graphically represented in the Figure -I.

Figure-I

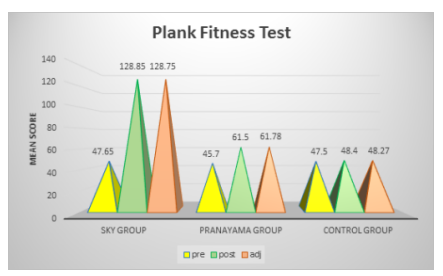

\section{CONCLUSIONS:}

Based on the final result of the study the following conclusions were drawn.

1. There was a major difference between SKY yoga with Kayakalpa group and SKY yoga group when compared to the control group on physical variables of Plank Fitness test.

2. SKY yoga with Kayakalpa was found to be better than the SKY yoga only practicing group and control group in physical variables of Plank Fitness test. That showed that when SKY yoga with Kayakalpa has induced more in the aging factor when this get influenced it shows in the form of stability, tissues, muscles etc., which is measured in this study.

\section{RECOMIMENDATIONS:}

1. A similar study may be conducted by selecting other Physiological variables as principle variables.

2. A similar study may be conducted by selecting Performance related variables as criterion variables.

3. A related study may be endeavored by selecting other psychological variable for the subjects.

\section{REFERENCES}

1. Chaya MS,et.al. (2006). "The Effect of Long Term CombinedYoga Practice on The Basal Metabolic Rate of Healthy Adults". BMC Complement Altern Med.31;PP.6:28.

2. Chiriac S, et.al. (2002), "The beneficial effect of physical training in hypertension", Rev Med Chir Soc Med Nat Iasi. 107(2):258-63

3. Lakka TA, and Laaksonen DE. (2007), "Physical activity in prevention and treatment of the metabolic syndrome.",Appl Physiol Nutr Metab.32(1):76-88.

www.vethathiri.org.in

5. www.topendsports.com 